\title{
Osteochondral mosaicplasty along with osteochondroplasty of the femoral head in femoroacetabular impingement: a case report
}

\author{
Femoroasetabüler sıkışmada femur başının tıraşlanması ile birlikte osteokondral mozaikplasti: \\ Olgu sunumu
}

\author{
Harun R. Güngör, MD., ${ }^{1}$ Esat Kıter, MD., ${ }^{1}$ Nusret Ök, MD., ${ }^{1}$ Adem Çatak, MD. ${ }^{2}$ \\ 'Department of Orthopedics and Traumatology, Medical Faculty of Pamukkale University, Denizli, Turkey \\ ${ }^{2}$ Department of Orthopedics and Traumatology, Tavas State Hospital, Denizli, Turkey
}

\begin{abstract}
Although femoroacetabular impingement (FAI) syndrome is included in the etiology of lesions involving the acetabular labrum and acetabular cartilage, it is one of many possible reasons behind osteochondral lesions in the femoral head. Herein, we present clinical findings and outcomes of two cases with osteochondral defects and cam type impingement of femoral head. Both cases underwent autologous osteochondral mosaicplasty along with femoral osteochondroplasty following controlled hip dislocation. Harris hip scores improved significantly postoperatively and magnetic resonance imaging showed an adequate graft union and formation of a healthy chondral surface at the final assessment. Autologous osteochondral mosaicplasty of parafoveal region defects and femoral neck osteochondroplasty combination may be an effective treatment method for young patients with FAI syndrome. In addition, we believe that cam type impingement may also have a role in the etiology of parafoveal osteochondral lesions.
\end{abstract}

Keywords: Cam type impingement; femoroacetabular impingement; hip; mosaicplasty; osteochondral lesion.

Osteoarthritis of the hip results from mechanical, biological, and biochemical factors. ${ }^{[1]}$ Recently, hip preservation surgery has become popular for the treatment of osteochondral defects in the femoral head. This is particularly true following the success of microfracture methods applied to osteochondral lesions of the femoral head in the treatment of femoroacetabular impingement (FAI) syndrome. Indeed, reconstruction of the femoral
$\ddot{O} Z$

Femoroasetabüler sıkışma (FAS) sendromu asetabüler labrum ve asetabüler kıkırdak lezyonlarının etyolojisinde yer almasına rağmen, femur başındaki lezyonların arkasındaki birçok olası nedenlerinden biridir. Bu yazıda, femur başında osteokondral defekt ve cam tipi sıkışması olan iki olgunun klinik bulguları ve sonuçları sunuldu. Her iki olguya da kontrollü kalça çıkarılmasını takiben, otolog osteokondral mozaikplasti ile birlikte femoral tıraşlama uygulandı. Ameliyat sonrası Harris kalça skorları anlamlı düzeyde iyileşti ve son değerlendirmede elde edilen manyetik rezonans görüntülemede yeterli greft kaynaması ve sağlıklı kondral yüzey oluşumu tespit edildi. Parafoveal bölgedeki defektlerin otolog osteokondral mozaikplastisi ve femoral boyun tıraşlanması birlikteliği, FAS sendromlu genç hastalarda etkili bir tedavi yöntemi olabilir. Ayrıca, cam tipi sıkışmanın, parafoveal osteokondral lezyonların etyolojisinde rol alabileceği düşüncesindeyiz.

Anahtar sözcükler: Cam tipi sıkışma; femoroasetabüler sıkışma; kalça; mozaikplasti; osteokondral lezyon.

head with osteochondral autograft transfer system (OATS) via hip dislocation is a promising and novel alternative in the treatment of chondral defects of the hip. ${ }^{[2]}$ However, the etiology of the osteochondral defects of the hip joint is extremely complicated and the relationship between FAI and osteochondral lesions of the femoral head has not yet been adequately studied in the literature. ${ }^{[3-6]}$ Herein, we aim to demonstrate that a combination of OATS

\footnotetext{
- Received: February 17, 2015 Accepted: May 07, 2015
}

- Correspondence: Esat Kıter, M.D. Pamukkale Üniversitesi Tıp Fakültesi Ortopedi ve Travmatoloji Anabilim Dalı, 20070 Kınıklı, Denizli, Turkey. Tel: +90 258 - 4440827 Fax: +90258-296 6001 e-mail: esatkiter@gmail.com 
and femoral neck osteochondroplasty can be an appropriate treatment modality for FAI, while taking possible involvement of cam impingement in the etiology of parafoveal osteochondral lesions of the femoral head in FAI into consideration. We present two cases of cam impingement and osteochondral defects in the parafoveal region of the femoral head. Both cases were treated with open OATS and femoral neck osteochondroplasty. The patients and their family members were informed that data from the cases would be submitted for publication and their consent was obtained.

\section{CASE REPORT}

Two female patients presented to our clinic with hip pain and both underwent surgery due to femoral defects and cam impingement (Figures 1a and 2a). Medical history of both patients revealed no previous hip problems, trauma, or comorbidity. The patients' characteristics are shown in Table I.

As described by Ganz et al., ${ }^{[7]}$ the patients received surgical hip dislocation. The chondral defects and subchondral cysts in the parafoveal region of the femoral head were debrided. The cam impingement was subjected to osteochondroplasty using a high-speed drill and the defect size was measured (Case 1, $2.7 \mathrm{~cm}^{2}$; Case 2, $3.6 \mathrm{~cm}^{2}$ ). Using the Arthrex osteochondral autograft transplantation system (OATS; Arthrex Inc., Naples, Florida, USA), the osteochondral cylinders were removed from the ipsilateral anterolateral femoral condyle. Following the preparation of the graft bed, the necrotic graft beds were drilled to the viable bone in both cases. Drilling was applied vertically to the center of the femoral head, by preserving the form of the graft bed. The defect was augmented with an allograft and the graft cylinders were stabilized over the surface (Figures 1b, 2b). The accuracy grafted femoral head curvature was confirmed and hip reduction was established and the capsule was repaired. The trochanteric osteotomy was fixed with two $6.5 \mathrm{~mm}$ cannulated screws.

Postoperatively, the patients were mobilized with no weight loading on the hip for eight weeks.
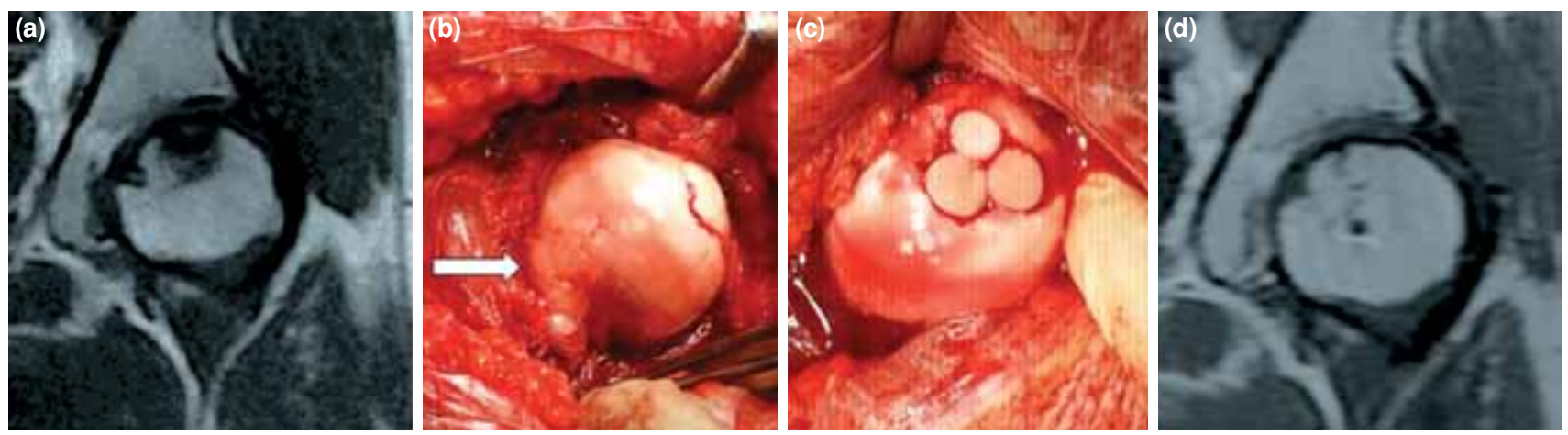

Figure 1. Preoperative, intraoperative, and postoperative images of case 1. (a) Preoperative magnetic resonance imaging, (b) intraoperative cam impingement (arrow), (c) intraoperative final construction of mosaicplasty, and (d) the recent follow-up magnetic resonance imaging scan at month 14.
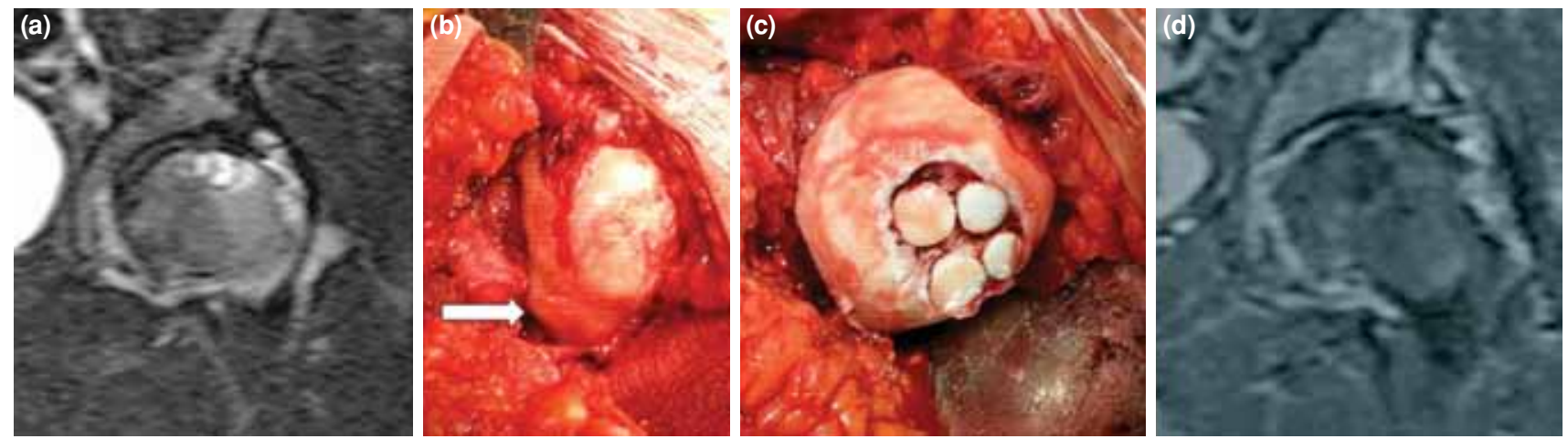

Figure 2. Preoperative, intraoperative, and postoperative images of case 2. (a) Preoperative magnetic resonance imaging, (b) intraoperative cam impingement (arrow), (c) intraoperative final construction of mosaicplasty, and (d) the recent follow-up magnetic resonance imaging scan at month 12. 
TABLE I

Patient characteristics and hip lesions

\begin{tabular}{lcc}
\hline & Case 1 & Case 2 \\
\hline Age (years) & 22 years & 23 years \\
Site & Left hip & Left hip \\
Profession & Dancer & Clerk \\
Initiation of symptoms & 18 months & 6 months \\
Tönnis stage & 1 & 2 \\
Defect location & Parafoveal & Parafoveal \\
Defect size (cm) & $1.8 \times 1.5$ & $2 \times 1.8$ \\
Grafts used (mm) & $10,8,8$ & $10,10,8,8$ \\
Allograft augment & Yes & Yes \\
Preoperative Harris score & 52 & 46 \\
Follow-up period & 14 months & 12 months \\
Postoperative Harris score & 93 & 85 \\
\hline
\end{tabular}

Both were allowed for partial weight bearing at eight weeks, and full weight bearing at 12 weeks. The final assessment (Case 1: 14 months and Case 2: 12 months) revealed a full range of motion and the patients were able to perform daily activities without pain or antalgic gait. Follow-up magnetic resonance imaging showed an adequate graft union and formation of a healthy chondral surface.

\section{DISCUSSION}

In the past 12 years, based on the original definition of FAI syndrome, the importance of hip preservation surgery has increased significantly. ${ }^{[2-7]}$ Cartilage preservation surgery in the hip joint has several limitations due to the difficulties inherent in exposing the chondral area. With the introduction of advanced arthroscopic methods and controlled hip dislocation defined by Ganz et al., ${ }^{[7]}$ joint preservation surgery has gained popularity for the treatment of chondral lesions of the hip. Unfortunately, there is limited data in the literature on methods such as arthroscopic debridement, repair of the acetabular labrum, femoral neck osteochondroplasty, microfracture and bone marrow stimulation, autogenous chondrocyte implantation, and allograft transplantation. ${ }^{[2-6]}$

There are several studies which report successful treatment of chondral defects by OATS, regardless of the underlying etiology. ${ }^{[2,8-10]}$ In these studies, chondral defects of the femoral head with various etiologies have been treated with autogenous osteochondral grafts. The most common etiologies reported in the literature include avascular necrosis, trauma, Legg-Calve-Perthes disease, and epiphyseal dysplasia sequelae. ${ }^{[8-11]}$ With the exception of the five-case study described by Rittmeister et al. ${ }^{[1]}$ previous study findings are promising.

Furthermore, osteochondral lesions of the femoral head may result from many underlying causes. The most common causes of isolated lesions are osteonecrosis, lateral impact syndrome, osteochondritis dissecans, and the presence of loose bodies. ${ }^{[12]}$ Femoroacetabular impingement syndrome plays a significant role in the pathogenesis of hip chondral lesions. Beck et al. ${ }^{[3]}$ defined acetabular cartilage defects induced by various mechanisms of pincer and cam impingement. However, there is a limited number of data on the osteochondral impingement of the femoral head associated with FAI syndrome. Patients with cam lesions have restricted hip movements and disregulated biomechanical properties of the hip and pelvis.

Charbonnier et al. ${ }^{[4]}$ showed that, in the presence of FAI, the pathology is different than that of a simple local impingement and that the hip shows a temporary subluxation. Thus, in the presence of FAI, translational hip movements may subject the entire joint to the deformation loads. In a study including 10 patients with both osteochondral defects of the femoral head and cam impingement, Zaltz and Leunig ${ }^{[2]}$ showed that the instability resulting from the misaligned joint and the resulting shear forces might play a role in the injury of the femoral head cartilage. They performed femoral neck osteochondroplasty on all those patients. The femoral defect was treated with only microfracture in seven patients and with microfracture plus AMIC (autologous matrix-induced chondrogenesis) in three patients.

In terms of surgical technique, both of our cases had a graft bed with a floor containing hard and necrotic bone tissue. Therefore, we had to drill to the viable tissue. Although this is a risky step for the stabilization of the graft, it is essential to maintain its viability. A drill deepened the cavity, and, then, allograft filler stabilized the grafts. In their case series, Gagala et al..$^{[8]}$ reached the healthy bone with a similar modality. This condition not only occurs in acute trauma, but also in chondral lesions associated with a chondral etiology.

In this case study, we treated two cases with cam impingement plus chondral defects of the femoral head through the combined application of OATS and femoral neck osteochondroplasty. To the best of our knowledge, there is no report of such a combination therapy in the literature. Nevertheless, these two cases support the hypothesis that cam impingement 
may lead to chondral defects in the femoral head, as there is no etiological factor documented other than this. ${ }^{[2,4]}$ Although the parafoveal region is located far from the CAM impingement, gross effect of translational movements and temporary subluxation may cause the lesions on the femoral head, as suggested by Charbonnier et al. ${ }^{[4]}$ The presence of femoral chondral defects in cases of FAI-related progressive arthrosis is not surprising. However, our both patients were young and the joint range of motion was preserved. The aim of this report is to demonstrate that OATS combined with femoral neck osteochondroplasty is an effective treatment modality for this patient population and to highlight the necessity of analysis of the underlying etiology. It suggests the possible involvement of CAM impingement in the development of chondral defects in the parafoveal region of the femoral head.

\section{Declaration of conflicting interests}

The authors declared no conflicts of interest with respect to the authorship and/or publication of this article.

\section{Funding}

The authors received no financial support for the research and/or authorship of this article.

\section{REFERENCES}

1. Atik OŞ. The role of metabolomics in osteoarthritis for early diagnosis, monitoring prognosis and treatment. Eklem Hastalik Cerrahisi 2015;26:1.

2. Zaltz I, Leunig M. Parafoveal chondral defects associated with femoroacetabular impingement. Clin Orthop Relat
Res 2012;470:3383-9.

3. Beck M, Kalhor M, Leunig M, Ganz R. Hip morphology influences the pattern of damage to the acetabular cartilage: femoroacetabular impingement as a cause of early osteoarthritis of the hip. J Bone Joint Surg Br 2005;87:1012-8.

4. Charbonnier C, Kolo FC, Duthon VB, Magnenat-Thalmann N, Becker CD, Hoffmeyer P, et al. Assessment of congruence and impingement of the hip joint in professional ballet dancers: a motion capture study. Am J Sports Med 2011;39:557-66.

5. Koçkara N, Bursali A, Issin A, Gürsu SS, Yildirim T, Sahin $\mathrm{V}$. Is open surgery effective in early-term in patients with femoroacetabular impingement syndrome?. [Article in Turkish] Eklem Hastalik Cerrahisi 2012;23:72-6.

6. Sahin N, Atici T, Oztürk A, Ozkaya G, Avcu B, Ozkan Y. The relationship between chronic hip pain and femoroacetabular impingement: an evaluation with clinical signs and radiography. [Article in Turkish] Eklem Hastalik Cerrahisi 2011;22:129-33.

7. Ganz R, Parvizi J, Beck M, Leunig M, Nötzli H, Siebenrock KA. Femoroacetabular impingement: a cause for osteoarthritis of the hip. Clin Orthop Relat Res 2003;417:112-20.

8. Gagala J, Tarczyńska M, Gawęda K. Clinical and radiological outcomes of treatment of avascular necrosis of the femoral head using autologous osteochondral transfer (mosaicplasty): preliminary report. Int Orthop 2013;37:1239-44.

9. Krych AJ, Lorich DG, Kelly BT. Osteochondral autograft transfer for a posttraumatic osteochondral defect of the femoral head. Am J Orthop (Belle Mead NJ) 2012;41:472-6.

10. Nam D, Shindle MK, Buly RL, Kelly BT, Lorich DG. Traumatic osteochondral injury of the femoral head treated by mosaicplasty: a report of two cases. HSS J 2010;6:228-34.

11. Rittmeister M, Hochmuth K, Kriener S, Richolt J. Five-year results following autogenous osteochondral transplantation to the femoral head. Orthopade 2005;34:322-6. [Abstract]

12. Byrd JW. Lateral impact injury. A source of occult hip pathology. Clin Sports Med 2001;20:801-15. 